\title{
Conceptions of Gender and Competencies among Police Recruits in Scandinavia'
}

\author{
I Lotte Bloksgaard \\ PhD, former Associate Professor at Aalborg University, Denmark
}

\section{Silje Bringsrud Fekjær}

Professor at Oslo Metropolitan University, Centre for the Study of Professions, Norway

\section{Rasmus Juul Møberg²}

Associate Professor at Aalborg University, Department of Sociology and Social Work, Denmark

\begin{abstract}
Conceptions of gender and competencies may be of importance for the gendered allocation of tasks and may help explain gender segregation in the labor market and within organizations. Drawing on survey panel data from Scandinavian police recruits in the male-dominated police profession, this article explores and discusses the prevalence of conceptions of gender and different police competencies. A substantial portion of the police recruits disagree that men are more competent at specific police tasks (handling violence) and women at others (care and communication). However, quite a large minority have more stereotypical conceptions of gender and competencies. Male police recruits generally report more gender-stereotypical conceptions than female and this tendency increases over time after entering the police. Furthermore, the Danish police recruits report the most gender-stereotypical conceptions, while the Swedish recruits more often dismiss the idea that men and women are suited for different police tasks.
\end{abstract}

\section{KEYWORDS}

Competencies / gendered organizations / gender segregation / gender stereotypes / police work

\section{Introduction}

hen we measure, discuss and compare gender segregation in the labor market,
the focus is often gender segregation at the macro level, also termed occupational
segregation, and changes over time (Bettio \& Verashchagina 2009; Charles \&
Grusky 2004; Reisel \& Teigen 2014). However, the gender segregation taking place
within occupations and organizations is not included in these analyses. Research indi-
cates that 'gender segregation at the job level is more extensive than gender segrega-
tion at the level of occupations' (Wharton 2005, p. 97) and shows that women and
men working in the same occupation, despite having the same education and seniority,
often have different tasks, working conditions, wages and opportunities for promotion
(Holt \& Lewis 2011; Wharton 2005). Thus, analyses at the macro level 'underestimate

\footnotetext{
${ }^{1}$ You can find this text and its DOI at https://tidsskrift.dk/njwls/index.

${ }^{2}$ Corresponding author: rim@socsci.aau.dk.
} 
the degree to which women and men work in different jobs' (Wharton 2005, p. 97) and experience different conditions and opportunities in work life. The research on gender and organizations documents that gendered processes in organizations are central to understanding gender segregation as an ongoing process, actively created, changed and recreated (Acker 1990; 2012; Gherardi 1994). Presently, we lack sufficient knowledge about gendering, especially regarding the male-dominated occupations that women are increasingly entering, and studies that include both women and men in these occupations (Ellingsæter 2013; Holt \& Lewis 2011).

Studies of organizations have shown that cultural assumptions and stereotypical conceptions of gender linked to specific work tasks and fields of competency are central to the allocation of tasks. Stereotypical conceptions of gender is the belief that men and women are inherently different and 'possess' different/opposite qualities (Acker 1990; Bloksgaard 2008; Holt \& Lewis 2011; Holt et al. 2006). If men and women are perceived as suited for different tasks, this may affect their own and others' assumptions about what kind of work they should do and may therefore contribute to explaining gender segregation. However, there are still few quantitative and comparative studies of specific occupations that can reveal how widespread (non-)stereotypical conceptions of gender and competencies are and how these conceptions vary across groups and across countries.

In this article, we analyze the following research questions: To what extent do Scandinavian police recruits perceive men and women to be equally suited for different types of police work? And how do conceptions of gender and police tasks vary depending on the recruits' gender, experience, country of origin (Sweden, Norway or Denmark) and other background characteristics?

We focus on the Scandinavian police recruits for several reasons: In addition to being numerically male-dominated, the police has traditionally been associated with masculinity - action, use of force and physical strength - and a specific form of masculinity - white, heterosexual and working-class (Andersson 2003; Larsson 2010). However, over the last decade, there have been a number of politically and organizationally driven changes in the police, possibly challenging the traditional conceptions of policing and the core tasks of the occupation. Generally, in Western countries, there has been a movement from 'policing by force' to 'policing by consent' (Reiner 2010). In Scandinavian countries, the ideal of 'minimal-use-of-force' and conflict solving via communication is central, and there is an extensive focus on communicative and relational skills in the recruitment and training of police recruits (Bloksgaard \& Prieur forthcoming; Lagestad 2012). In addition, the professionalization of the police profession in the Scandinavian countries has led to an emphasis on the reflective and analytical police officer. Furthermore, the Scandinavian police organizations have policies promoting gender equality and diversity (Finstad 2014; Inzunza 2015).

Thus, there has recently been a focus on attracting 'another type' of police recruit into Scandinavian police organizations distinct from 'the masculine crime fighter' type (Gundhus 2013) to obtain a more diverse 'police corpus' integrating multiple competencies. Concurrently, new research finds that traditional conceptions of police work (as crime fighting) and who is suited for this type of work (physically strong/male bodies) are still dominant in the media and within the police profession (e.g., Karp \& Stenmark 2011; Lander 2013; Loftus 2010). Thus, it is central to explore the conceptions regarding who is suited for different types of police work that exist among police recruits. The 
conceptions of gender and competencies in the police force may of course differ from those found among the new recruits. However, the conceptions of new recruits are of interest, both because they could be an indicator of conceptions in the police force, and, more importantly, because they compose the police force of tomorrow and are believed to bring change and diversity into the police organization (Karp \& Stenmark 2011). Furthermore, the Scandinavian countries are relevant for this study, as they are known for their commitment to gender equality, and they stand out from the other EU countries in terms of their relatively small gender gaps and high scores on gender equality measures (Teigen \& Skjeie 2017). However, the Scandinavian countries still have segregated labor markets (e.g. Bettio \& Verashchagina 2009; Charles \& Grusky 2004; Reisel \& Teigen 2014). In addition, the Scandinavian countries differ somewhat in respect to gender balance; Sweden is the most gender balanced with Denmark in the opposite end, at least in the economic equity dimension (Teigen \& Skjeie 2017).

\section{Theoretical Perspectives on Gender and Competencies in Organizations}

The article draws on theories about gender and organizations that illustrate how assumptions about and conceptions of gender contribute to the (re)production of gender differences and inequalities in work life. More specifically, we draw on three theoretical perspectives derived from Kanter (1977), Acker (1990, 2012) and Solheim (2002). All these perspectives illustrate the importance of exploring cultural images of and assumptions regarding gender in occupations and organizations, as these may influence structuring practices in work life, especially the allocation of work tasks, and thus help explain gender segregation in organizations and work life (Acker 1990, 2012; Chan et al. 2003; Gherardi 1994).

In her famous study, Men and Women of the Corporation (1977), Kanter introduces the term 'structure of opportunities' to capture the idea that gender differences in organizational behavior are caused by the structural placement of men and women rather than the characteristics and performance of individual women and men. Her aim is to break with the assumption that men and women are inherently different, since such assumptions are 'giving men an advantage in the business world and making women more suitable for support roles' (Kanter 1993 p. 292). Kanter finds that when numerically underrepresented (e.g., in management), women are at risk of being seen and treated as representatives for an ascribed category - their gender - and being placed in certain roles and given job tasks perceived to be suitable based on their gender. When women encounter such stereotypes, one strategy is accepting that their role will be to perform tasks that are seen as suitable for women (e.g., handling human relations instead of taking on leadership responsibility) (Kanter 1993). Thus, not only colleagues and leaders but also the women themselves may participate in the stereotypification.

Kanter concludes that it is the organizational structures - positions and numbers that explain the problems women face in organizations (Kanter 1993 p. 293). Thus, she does not include societal gender structures - the existence of 'a gender regime' within which a hegemonic masculinity is privileged (Connell 1987) - and that this may entail different opportunities for men and women within organizations. In her well-known theory of 'gendered organizations', Acker criticizes this omission and conceptualizes 
gender as a constitutive part of organizational processes, arguing that cultural assumptions about gender are imported from society and normatively reproduced in organizations (Acker 1990, 2012). Implicit beliefs in differences between men and women are embedded in the organizational culture, which 'usually includes definitions of gendered behaviors, both acceptable and unacceptable' (Acker 2012, p. 216). Thus, organizations routinely construct patterns of difference even if organizations think of and present themselves as gender-neutral, the organizational 'logic' is based on the imagery of men and masculinity. Previous research has described conceptions of an 'ideal' police officer, who is male, masculine, tall and physically strong (Chan et al. 2003; Lagestad 2012).

Focusing on the Scandinavian countries, which are known for a commitment to gender equality, Solheim (2002) theorizes about modern work life as an arena for the continued (re)production of hierarchical structures of gender. She argues that, codification and the assessment of competencies constitute a crucial basis for gendered categorization and ranking: the ranking does not apply to women and men, at least not in principle; rather, value is assigned to the professional qualifications and competencies that women and men are expected to possess and bring to the labor market (2002 p. 115-116), cf. also Acker (1990). Thus, competencies are what link value to gender, as certain tasks and competency fields are marked as female and male based on cultural ideas about female and male qualities. The division also implies a hierarchy, as the male competencies are held in higher regard than the female competencies. Thus, Solheim speaks of 'a gender-oriented regime of competencies' (2002, p. 118). For example, in the police, a 'man of the street' image is given high status both historically and today, whereas the indoor 'PC police' role is associated with women (Barrie \& Broomhall 2012; Gundhus 2009). Solheim (2002) emphasizes that gendered hierarchies are constantly changing and being reproduced in new forms. As interpersonal competency and communicative competency, for example, are given higher status in modern work life, a differentiation between different types of relational competency develops: certain types, that is, those linked to external work, become masculinely gendered and ascribed greater value (2002, p. 129-131).

In this article, we aim to analyze the conceptions of gender and competencies that men and women bring into and develop in the police organization in light of the three theoretical perspectives drawn from Kanter (1977), Acker (1990, 2012) and Solheim (2002). Especially, Acker's critic of Kanter's omission of the societal gender structure and Solheim's concept of gender-oriented regime of competencies will constitute the theoretical framework within which the explorative empirical analysis is unfolded.

\section{A Gendered Hierarchy of Police Competencies and Tasks}

In recent decades, there has been an increase in the proportion of women in the police services in many countries, although there are signs that this growth is levelling out (Prenzler \& Sinclair 2013). Women make up 34\% of the police force in Sweden (SCB 2018), 31\% in Norway (POD 2018) and 16\% in Denmark (Rigspolitiet 2018). The police is still numerically a male-dominated occupation in all countries. In addition, the police traditionally has been and still is a strongly masculinely gendered occupation involving authority, use of force and physical strength. The imagery of 'physicality' and 'toughness' as defining characteristics of police officers is linked to the legitimate use of

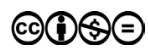


force in the exercise of police work (Barrie \& Broomhall 2012) and explains why police work has been constructed as a masculine competence field, cf. Solheim (2002), where men (and men's bodies) are seen as suited for policing, whereas women (and women's bodies) are seen as unsuited. Historically, this has been the main argument for barring women from the police and for the resistance reported by the first women employed in the police. These perceived gender differences were also the reason for employing the first female police officers: female officers were needed to take care of women and children and to frisk female offenders (Appier 1998; Finstad 2000).

Today, women are employed in the police to handle the same tasks as their male colleagues. In addition, new police tasks and demands for evidence-based policing and 'policing by consent' are potentially creating openings for a new type of police officer, in whom competencies such as interpersonal and communicative skills will be valued (Gundhus 2013). In a recent Norwegian study, police leaders claim that they regard female police officers as especially competent due to their 'feminine' skills, for example, communications. Thus, leaders express a belief of gender as difference and see the representation of women as an advantage (Nordberg 2018). The view that women are more competent due to social skills is, however, not prevalent in a Danish study of the recruitment, selection and training of police officers (Bloksgaard \& Prieur forthcoming).

In the Scandinavian police services, there has been an effort to put the ideal of policing by consent into practice, and this concept is now central to the education of new police officers in Scandinavia (Bloksgaard \& Prieur forthcoming; Inzunza 2015; Lagestad 2012). This new emphasis is reflected in the fact that Scandinavian police recruits, upon completion of their training, state that social/relational skills are more important for the professional competency of a police officer than physical skills (Bloksgaard et al. 2016; Olofsson \& Petersson 2011). However, research indicates that socialization into the police profession is strong and that norms and perceptions of police work at the 'street level' are not necessarily aligned with the official ideals of the police organization communicated via police educations (e.g., Granér 2004; Petersson 2015). The classic literature and research on the police role has shown that crime-fighting tasks, linked to action, the use of force and physical strength, were historically preferred among officers and considered to be the real work of the police (Reiner 2010). New research shows that there may still be a status hierarchy in the police occupation, according to which officers still consider the crime fighting role to be the 'real' police work (Atkinson 2017; Loftus 2010; Terpstra \& Schaap 2013). New Scandinavian research documents that police officers are still to a large extent oriented towards crime fighting, action and risk (Bille 2014; Mikkelsen 2018). Thus, despite new managerial strategies, cultural norms and conceptions of meaningful police work as involving danger and violence hence require physical strength and the use of force still persists, whereas other tasks are downgraded in the hierarchy. Although police officers agree that interpersonal skills and communicative competency are important in police work (Inzunza 2015; Lagestad 2012), such 'soft' competencies may still be lower in the competency hierarchy.

Gundhus analyzes gendered practices and the competence hierarchy in the Norwegian police and shows that they reproduce the modern gendered competency hierarchy, cf. Solheim (2002). The tasks at the bottom of the prestige hierarchy (preventive policing, caregiving, etc.) are tasks that women are perceived to be suited for, while the tasks at the top of the hierarchy, seen as 'real' police work (involving working 
the streets, use of force and action involving physical strength), are masculinely gendered (Gundhus 2009). The police tasks seen as feminine are ascribed lower status and resisted. Other new research in Scandinavia and in other European countries (Atkinson 2017; Lagestad 2012; Lander 2013; Loftus 2010) likewise finds that men are expected to exhibit the action-oriented masculinity of the physically strong officer, whereas women, seen as unsuited for the crime-fighting role, are 'marginalized to the periphery of policing'(Atkinson 2017, p. 244). These studies indicate that the prevailing image of the crime-fighting role reproduces the gendering of police tasks and the gendered competence hierarchy in the police.

Studies focusing on how conceptions of police competencies are linked to gender are generally sparse, and many are qualitative studies, which, as valuable as they are, provide limited knowledge on how widespread gender-stereotypical conceptions of police competencies and tasks are. An exception is an American study of SWAT team officers which shows that male officers are more likely to think that female officers lack the strength and skills to perform the job as a SWAT team member (Dodge et al. 2011). Another interesting quantitative study is conducted among Dutch police officers by Terpstra and Schaap (2013), which revealed that for the majority of officers, the image of police work is strongly linked to physical strength and courage. Concurrently, only a small minority of the respondents in the study of Terpstra and Schaap (2013) disagree with the statement that 'women can do the job as well as men'. However, in a Danish quantitative study, Kjellman and Møberg (2018) find that police recruits tend to underreport gender-stereotypical conceptions when answering more generally formulated questions about women's suitability for police work compared to their responses to questions concerning more specific police tasks and gender. This methodological point indicates that survey questions on specific police tasks are better at measuring potential gender-stereotypical conceptions than more general statements on gender difference.

\section{Data and Methods}

The data in this article are drawn from the international research project RECPOL (Recruitment, Education and Careers in the Police), which follows police recruits over time via surveys. The entire cohorts of recruits were asked to participate. The response rate was generally very high, varying between $83 \%$ and $97 \%$ (with the exception of Norway in phase two; $69 \%$, probably due to administrative challenges). The data are from 1346 police recruits in total from Sweden $(\mathrm{N}=350)$, Norway $(\mathrm{N}=637)$ and Denmark $(\mathrm{N}=359)$. Official approval from the police colleges and the fact that the surveys were completed in class probably explain the unusually high response rates.

The phase one data are collected when the police recruits begin their education (2010 in Norway, 2011 in Sweden and 2012-2013 in Denmark). This means that they are new in the police profession but have most likely experienced pre-socialization in the recruitment and selection process to become police officers, which means that they to some degree already have taken on values, attitudes, skills, and knowledge that they believe characterize the organization and the organizational group to which they aspire. Pre-socialization is found to be strong in the police profession due to very explicit admission requirements and a through selection process (Chan et al. 2003; Van Maanen 1973). The police recruits are asked the same questions about gender and police tasks 
(see below) when they finish their police education (phase two: 2013 in Norway and Sweden and 2015-2016 in Denmark).

We measure conceptions of gender and competencies using three statements: 'Male police officers are better suited than female officers at handling situations involving violence', 'Female police officers are better than male officers at caring for women and children' and 'Female police officers are better at communicating than male officers'. The three statements are worded in a gender-stereotypical way linking competencies and gender and, thus, measuring the police recruits' support of gender stereotypes.

We have chosen the three survey items, which according to Solheim's (2002) and Gundhus' (2009) empirical studies are situated at different places in the gender hierarchy. 'Handling situations involving violence' is at the top; and 'caring for women and children' is at the bottom of the gender hierarchy. Communication is traditionally seen as a competence ascribed to the female gender but has moved towards a more genderneutral status (Gundhus 2009). Individually, the survey items contribute to the analysis of the presence and development of specific gender stereotypical conception among the Scandinavian police recruits. Together, the survey items indicate a general presence of gender stereotypical conceptions, which potentially can affect the opportunity structure within the police.

In the analysis, an index consisting of the combined score of the three single items is constructed to reduce the effect of measurement errors and capture an overall concept of gender and competencies, which is difficult to measure when using single items (see Figures 1-3 for the distribution of the individual items). A Cronbach's alpha test $(\mathrm{CA}=0.75)$ shows a high intra-item correlation between the three variables. The index score is derived by adding the scores of the individual items and dividing the sum by the total number of items ${ }^{1}$ ( mean $=1.6, \mathrm{SD}=1.0$ ). Theoretically, the index ranges from ' 0 ', indicating that gender is not related to how competent the individual police recruit is at different tasks, to '4', indicating that gender is related. In the analysis, the index will be treated as a continuously scaled variable.

Social desirability bias implies that people may answer surveys according to what is presumed to be socially acceptable in the specific social context they are part of and not according to their true opinions (Podsakoff et al. 2003). In our case, this means that we would expect police recruits in Scandinavia to under-report support for the genderstereotypical questions in the survey. The results presented in this article therefore probably represent a minimum prevalence of gender-stereotypical conceptions among police recruits in Scandinavia.

Finally, previous research has shown the importance of background variables for attitudes towards gender equality. The most positive attitudes towards gender equality are found among women, the younger generations, people with a higher education level and those who have highly educated parents (Davis \& Greenstein 2009). Hence, we also control for crucial background variables: gender, age, previous education and parents' education. Gender is coded 0 for males $(66 \%)$ and 1 for females $(34 \%)$. The percentage of females varies across countries, from $21 \%$ in Denmark to $36 \%$ in Norway and $38 \%$ in Sweden. Age is set to 20 years = 0, 21 years $=1$, etc. $($ mean $=24.8$ years, $S D=3.9)$. Previous education is divided into 0: no higher education $(63 \%)$ and 1 : higher education at the post-upper secondary level (37\%). Parents' education is divided into 0: no higher education $(29 \%), 1$ : at least one parent with some higher education at the post-upper secondary level $(67 \%)$ and 2: other/don't know (4\%). 


\section{Conceptions of Gender and Police Tasks among Male and Female Police Recruits in Scandinavia}

Overall, a substantial portion of the recruits disagree when asked whether male officers are better suited for some tasks and female officers for others; thus, these recruits reject the perception that police tasks are gendered. However, we also find that quite a large minority agree that gender does matter for performing different police tasks, that is, that male police officers are better suited to handling situations involving violence and that female officers are better at communication and caring for women and children. In addition, a substantial portion of the recruits are ambivalent towards these questions. ${ }^{2}$

Analyzing the questions separately (see Figures 1-3) reveals small but noteworthy differences in the support for the three gender stereotypes, both between and within gender and over time. Of the three statements posed in phase one, the statement about women being better suited to caring tasks was agreed to by the largest proportions of male and female police recruits (see Figures 1-3). Thirty-nine percent and 30\% of male and female police recruits, respectively, agree with this statement to some extent (Figure 3). Thus, the idea that care is 'natural' for women, even in professional contexts, is the strongest of the three conceptions among the police recruits at organizational entry. Caring for women and

Figure I Male police officers are better suited than female police officers at handling situations involving violence (\%).

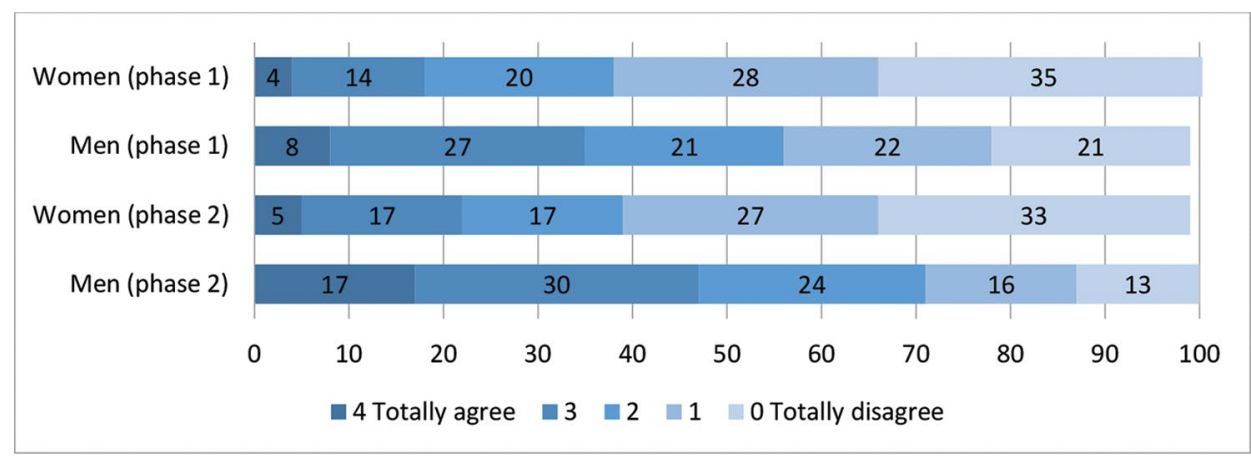

Figure 2 Female police officers are better at communicating than male officers (\%).

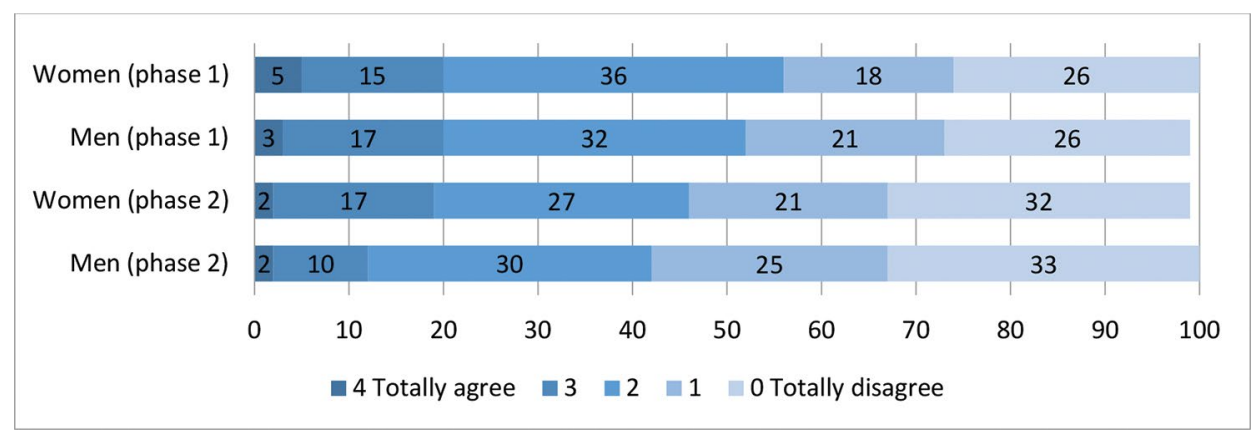


Figure 3 Female police officers are better than male officers at caring for women and children (\%).

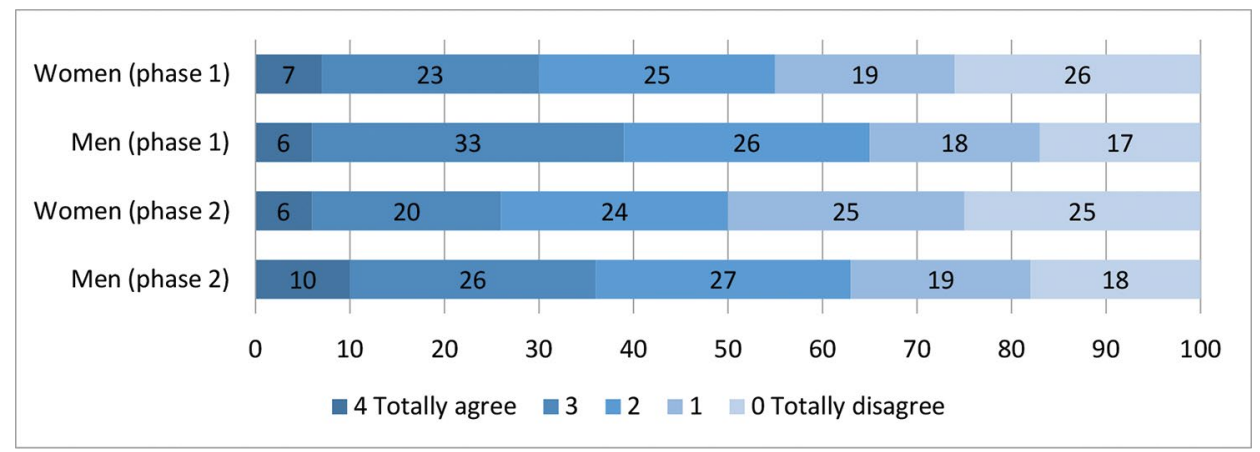

children is the police task that is the most strongly (femininely) gendered. In addition, this conception is more prevalent among the male police recruits, ${ }^{3}$ which means that the female recruits have male colleagues that to a higher degree perceive women as better suited for 'softer' police tasks than the women do themselves. Interestingly, even though female police recruits are a highly selected group who have defied gender-stereotypical expectations by choosing a nontraditional profession, $30 \%$ of them agree to some extent that women are better suited for police tasks involving care, showing that women are also reproducing the gendered competence hierarchy, cf. Solheim (2002). The analysis shows that the idea that women are better suited for police tasks involving care is stable over time, as there is no statistically significant change in either male ${ }^{4}$ or female ${ }^{5}$ recruits' agreement with this statement from organizational entry to completion of the police education program.

The statement about men being better at handling violent situations (Figure 1) shows larger gender differences, as agreement with this idea is markedly more predominant among male police recruits. Thus, at organizational entry, $35 \%$ of the male police recruits agree to some extent that male officers are better at handling violent situations, compared to only $18 \%$ of female police recruits. ${ }^{6}$ This result indicates that the female police recruits in general are more confident that they can handle violent situations. However, they have male colleagues that are more skeptical about female police officers being able to handle violent situations. Again, it should be noted that differences in conceptions of gender and competencies are observed both among the males and among the females: a large proportion of the males $(43 \%)$ to some extent disagree with the statement that male police officers are better suited to handle violent situations, thereby indicating that gender is not related to competency or is only weakly related. Additionally, $18 \%$ of female police recruits do agree to some extent with this stereotype. However, the gender difference in the perception of men's and women's suitability for handling violent situations increases over time: whereas the proportion of female recruits who agree to some extent that men are better at handling violent situations is virtually unchanged from organizational entry to completion of the police education, ${ }^{7}$ we observe an increase in the proportion of male recruits that to some extent agree that men are better suited for this police task, from $35 \%$ to $47 \% .^{8}$ This means that at the end of the education, more male police recruits agree that men are better suited to handle violent situations than agree to the statement about women being better suited to caring tasks. ${ }^{9}$ 
Finally, concerning the statement about women being better at communication, $20 \%$ of both male and female recruits agree, while nearly every second male and female police recruit disagree to some extent. These results indicate that communication skills are not perceived to be as femininely gendered (as care tasks). This result is interesting, as Solheim (2002) stresses that the gendering of competence fields may change over time, as the status of these fields in work life is changing. The results in this article could be seen as an indication that communicative competencies are becoming more androgynous - in other words, the majority of both male and female recruits perceive communication as a competency that men are also suited to perform in police work. At organizational entry, no gender difference can be observed. However, at the end of the education, the male police recruits agree to a lesser extent that female police officers are better at communication. ${ }^{10}$ Thus, at the end of the education, male officers to a larger extent see their own gender as suited to perform communicative tasks. This is interesting in the case of the police, as communicative skills have become of higher value concurrently with 'policing by consent' becoming the official ideal (Reiner 2010).

In summary, the results show that many of the police recruits do not agree that police tasks are gendered in the sense that male officers are more competent at handling violence and female officers at caring and communication. However, a large minority believe that gender does matter for competency in performing these specific police tasks. Their answers reflect a well-known gender stereotype: 'Violence is for men, care is for women'. The gender-stereotypical conceptions of police tasks are more widespread among male police recruits. Among the male recruits, the conception that men are better at handling violence and the conception that men are equally suited to communication increase after their entry into the police. Even though the analysis shows that changes in the perceptions occur, the design of the study and the data retrieved do not make it possible to discern how these changes are related to the teaching on the police academy and the exposure to the practical police work at the local police stations.

\section{Conceptions of Gender and Police Tasks - do Country, Age and Educational Background Matter?}

Do police recruits from different countries, age groups and educational backgrounds have different conceptions of how police competencies are linked to gender? We explore this question utilizing the index combining the three questions on gender and police tasks (concerning violence, communicating and caring) in Table 1. We show the results of a multivariate OLS regression model in which gender is introduced in model 1 and the background characteristics are introduced in model 2.

Model 1 shows that male police recruits tend to more often believe that men and women are unequally suited for different types of police work. Men score 0.26 points higher than women on the scale of gendered competencies, which ranges from 0 to 4 , a significant, although not very large, difference. Thus, the results from Figures 1-3 are also confirmed when we choose a different methodological angle by combining the items in an index and applying OLS regression. It is also worth noting that the effect of gender is virtually unaffected by the addition of other explanatory variables in the regression analysis. Hence, male and female police recruits differ in their conceptions of gender and different police tasks, even when comparing those who are similar in terms of other background characteristics. 
Table I Conceptions of gender and police tasks based on gender and background characteristics.

\begin{tabular}{l|c|c|c|c}
\hline & \multicolumn{2}{c|}{ Model I } & \multicolumn{2}{c}{ Model 2 } \\
\hline Female & Coef. & $\mathbf{p}>|\mathbf{t}|$ & Coef. & $\mathbf{p}>|\mathbf{t}|$ \\
\hline Country (Sweden =) & -0.26 & 0.00 & -0.24 & 0.00 \\
\hline Denmark & & & & \\
\hline Norway & & & 0.49 & 0.00 \\
\hline Age (20 = 0) & & & 0.36 & 0.00 \\
\hline Own previous education (no higher education) & & & -0.03 & 0.00 \\
\hline Higher education & & & & \\
\hline Parents' education (no higher education) & & & & \\
\hline Higher education & & & 0.09 & 0.13 \\
\hline Other/don't know & & & 0.03 & 0.83 \\
\hline Constant & 1.73 & 0.00 & 1.54 & 0.00 \\
\hline Adjusted R & & & 0.08 & \\
\hline $\mathrm{n}$ & 0.01 & & 1278 & \\
\hline
\end{tabular}

The individual characteristics of the police recruits in terms of their own and their parents' educational backgrounds have no significant effect on the conceptions of gender and police tasks.

This finding implies that recruits' conceptions are independent of their own education and their parents' education. The significant and negative effect of age indicates that younger recruits are more likely to believe that men and women are unequally suited for different kinds of police work. However, the differences are not very large. ${ }^{11}$

Turning to country differences, we find quite large differences among the Scandinavian countries. The largest difference is found between Denmark and Sweden. Danish recruits score on average 0.49 higher than the Swedes on the index (which ranges from 0 to 4 ), indicating that the police recruits in Denmark are more likely to believe that male and female police officers are unequally competent at different kinds of police work. The Norwegian recruits are in between, however, closest to the Danish recruits. The Swedish police recruits' views tend to a greater degree towards refusing genderstereotypical conceptions and stand out as the exception.

\section{Concluding discussion}

Our results show that police recruits are divided in their conceptions of whether gender is linked to specific police competencies and tasks. A substantial portion of police recruits disagree when asked whether men are best suited for some police tasks (handling violent situations) and women for others (care and communication). Thus, these police recruits reject perceptions of different police competencies as gendered. However, a large minority agree that men and women are suited for different police tasks and thus report 
gender-stereotypical conceptions. At organizational entry, care is perceived as the most gendered competence; femininely. Communication skills are not perceived to be as feminine as care tasks. Handling violent situations is to some extent perceived as masculinely gendered, especially among male police recruits, and increasingly so over time. Over time, agreement with the statement that male police officers are better at handling violent situations and disagreement with the statement that female police officers are better at communicating become the most prevalent perceptions among male police recruits. Thus, male recruits are highly confident both in men's (their own) ability to handle violent situations and communicative tasks. However, the vast majority of female recruits remain confident in women's (their own) ability to handle violent situations throughout the research period. However, a minority of the female recruits agree that men are better suited to handle violent situations (and an even greater number agree that women are better suited to care tasks), showing that even women who choose a non-traditional profession for their gender report gender-stereotypical perceptions of gender and competency. Changes in gendered conceptions over time are primarily found among male police recruits, and consequently, we find that the majority of male police recruits have some form of genderstereotypical beliefs about police tasks at the end of the education. Whether these changes in gendered conceptions are caused by practical experiences, the organizational culture or other factors are difficult to judge based on our empirical design. However, we do note that the changes seem to be quite similar across countries, although the Swedish police education does not involve long periods of on-the-job training.

Since men make up the majority of the police force, their conceptions of gender and different police competencies may be important in terms of the tasks women are assigned and, thus, the opportunities they will have in the police organization (Kanter 1977). The prevalence of gender-stereotypical conceptions of competencies and work tasks in organizations may lead to (unintended) statistical discrimination and limit individuals' opportunities to choose jobs and careers freely. If one has coworkers and supervisors who presume that one is less competent for some tasks based on gender, this may structure one's opportunities and the tasks one is assigned - and the tasks one seeks out (cf. Kanter 1993). Also, Acker (1990, 2012) describes how gendered conceptions can result in reallife segregation. For example, if female officers are perceived to be less competent in situations involving violence, they are less likely to be assigned such tasks and to develop this task competency or seek out this kind of task. Hence, gendered conceptions of competencies may create structural barriers and decrease both men and women's opportunities when choosing tasks and specializations (Acker 1990; Kanter 1993). Recent studies indicate that the allocation of tasks may to some extent be based on gender and ethnicity in Scandinavian police organizations (Löfstrand \& Uhnoo 2014; Slot 2012).

Although our results clearly indicate quite widespread gender-stereotypical conceptions of police competencies, our design does not allow us to draw conclusions on whether these competencies are ranked hierarchically, with the male competencies held in higher regard than the female competencies. This hierarchically ranking is central in the theoretical understandings of gendered competencies (cf. Solheim 2002). Several previous studies of the police have reported a ranking of competencies with the ones traditionally seen as 'male' on top (e.g. 'toughness' and physical strength) (Barrie \& Broomhall 2012; Loftus 2010; Reiner 2010). But we also note new studies indicating some degree of change within the police, increasing the status of competencies traditionally seen as more 'soft' or 'feminine' (e.g., communicative competence) (Gundhus 2013; Inzunza 2015).

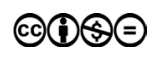


The research presented in this article only uncovers a few aspects relevant to the discussion of how and why 'real' police work is (still) masculinely gendered. In the article, the analysis is centered on the police recruits' conceptions and could be said to reflect the gender ideologies of the police recruits. How these ideologies relate to and are reflected in and affected by gender practices both at the police academy and at the local police stations cannot be determined in this empirical analysis. A question that goes beyond the scope of this article is whether the changes in recruits' conceptions are related to their experiences with police practices or with ideologies existing in the police. Thus, this article takes an initial step in exploring and explaining the relations among gender, competencies and police work in a Scandinavian context.

The findings of quite widespread gender-stereotypical conceptions of police competencies, even among police recruits in Scandinavia, point to the fact that the development towards more gender-balanced societies is neither gradual nor linear but rather uneven and contradictory. The fact that gender-segregated labor markets also exist in Scandinavia has been referred to as 'a gender equality paradox', but rather it shows the complexity of the process of social change, emphasizing that gender equality in one area does not automatically lead to gender equality in other areas (Borchorst 2011; Reisel \& Teigen 2014). Gendered conceptions in work life seem to be more resistant to change than in the private sphere (Ellingsæter \& Solheim 2002), and overall, societal ideologies about gender equality and 'equal opportunities' may coexist with more gender-stereotypical conceptions in regard to which jobs are perceived as suited for women or men (Bloksgaard et al. 2015; Charles \& Grusky 2004). As stated above, this article does not analyze how the gendered perceptions identified are related to gender practices. However, we believe that ideas about gendered fit to different types of work is one explanation for gender segregation within and between professions.

Our results also show large differences between the Scandinavian countries. The most gender-stereotypical conceptions are found among Danish police students, followed by Norwegian students, while Swedish students are the most likely to report that men and women are equally suited for different tasks. Although there is a tendency to think of the Scandinavian countries and their 'gender models' as if these were one and similar, there are considerable differences in gender policies and discourses in the three countries. Sweden has the most institutionalized gender model, gender is highly politicized and there is a strong discourse about gender equality, while in Denmark, the political significance of gender is limited, and there is a strong belief that gender equality has already been achieved. Norway is somewhere in the middle, with stronger institutionalization than Denmark and intermediate politicization of gender (Borchorst 2011). The country differences in our results reflect these differences. Additionally, the organizational contexts, including the proportion of female police officers, in the three countries differ. Unfortunately, our methodological design does not allow us to fully discern possible effects of the political/institutional and organizational levels.

Although the police, with its history as a male-dominated profession and emphasis on physical strength and possible violence, can be seen as an extreme case for studying gender and competency in modern work life, the police profession has many characteristics in common with other professions, for example, monopoly of certain tasks and a degree of discretion in work performance (Freidson 2001). Gendered conceptions of competency are likely to be found in other professions as well, and this can represent a challenge, especially if the goal is to change the profession. The police also makes an 
interesting case because the responsibilities involve both tasks traditionally seen as clearly 'male' (e.g., handling violent situations) and clearly 'female' (caring), a combination that also can be found in other professions. For example, working in the mental health services often involves caretaking, the possibility of violence and tasks that demands physical strength. Hence, gender-stereotypical conceptions of competencies may cause different work-life conditions and career paths for men and women in many professions and may contribute to explaining gender segregation in the labor market and in organizations.

\section{Disclosure Statement}

The authors declare that there is no conflict of interest.

\section{Author biographies}

Lotte Bloksgaard, PhD, former Associate Professor at Aalborg University, Denmark. Her research interests include gender, masculinity, inequalities, organizations and competencies in modern work life.

Silje Bringsrud Fekjeer, Professor at Oslo Metropolitan University, Centre for the Study of Professions, Norway. Her research interests include gender, social inequality, professional competencies and the police.

Rasmus Juul Møberg, Associate Professor at Aalborg University, Department of Sociology and Social Work, Denmark. His research interests include gender, professions, professional identities and education.

\section{References}

Acker, J. (1990). Hierarchies, jobs, bodies: A theory of gendered organizations, Gender and Society 4(2): 139-158. doi: https://doi.org/10.1177/089124390004002002.

Acker, J. (2012). Gendered organizations and intersectionality: Problems and possibilities, Equality, Diversity and Inclusion: An International Journal 31(3): 214-224. doi: https:// doi.org/10.1108/02610151211209072.

Andersson, S. (2003). Ordnade praktiker: En studie av status, homosocialitet och maskuliniteter utifrån två närpolisorganisationer [Arranged practices: A study of status, homosociality and masculinities in two local police organizations]. Available from ProQuest Dissertations \& Theses A\&I.

Appier, J. (1998). Policing Women: The Sexual Politics of Law Enforcement and the LAPD, Philadelphia: Temple University Press.

Atkinson, C. (2017). Patriarchy, gender, infantilisation: a cultural account of police intelligence work in Scotland, Australian \& New Zealand Journal of Criminology 50(2): 234-251. doi: https://doi.org/10.1177/0004865815626964.

Barrie, D. G., \& Broomhall, S. (ed.) (2012). A history of police and masculinities, 1700-2010. Abingdon, Oxon: Routledge. doi: https://doi.org/10.4324/9780203141427. 
Bettio, F., \& Verashchagina, A. (2009). Gender Segregation in the Labour Market: Root Causes, Implications and Policy Responses in the EU, Luxembourg: Publications Office of the European Union.

Bille, T. (2014). Politielevers levede erfaringer i praktikken. [Police students' lived experience during internship], Roskilde: Roskilde University.

Bloksgaard, L. (2008). Kompetencekrav, familiepolitikker og køn i moderne arbejdspladskontekster. [Competence demands, family policies and gender in a modern work place setting]. In R. Emerek \& H. Holt (Eds.), Lige muligheder - frie valg? Om det kønsopdelte arbejdsmarked gennem et årti, København: Socialforskningsinstituttet.

Bloksgaard, L., Christensen, A.-D., Jensen, S. Q., Hansen, Claus, D., Kyed, M. \& Nielsen, K. J. (2015). Masculinity ideals in a contemporary Danish context, NORA - Nordic Journal of Feminist and Gender Research 23(3): 152-170. doi: http://dx.doi.org/10.108 0/08038740.2015.1046918.

Bloksgaard, L., Møberg, R. J., \& Wenneberg Jørgensen, M. (2016). Ledelse og øvrige karrierespor i politiet: Nyuddannede politibetjentes forventninger om fremtidige arbejdsområder. [Management and other career tracks in the police: Newly educated police officers expectations for future areas of work] Internt paper: Rigspolitiet.

Bloksgaard, L., \& Prieur, A. (forthcoming) Policing by social skills. The importance of empathy and communication in the recruitment, selection and training of Danish police officers, Policing \& Society.

Borchorst, A. (2011). Scandinavian gender equality: Competing discourses and paradoxes. In E. Addis, P. de Villota, F. Degavre \& J. Eriksen (Eds.), Gender and well-being. The role of institutions (pp. 63-75), Farnham: Ashgate.

Chan, J. B. L., Devery, C., \& Doran, S. (2003). Fair Cop: Learning the Art of Policing, Toronto: University of Toronto Press.

Charles, M., \& Grusky, D. B. (2004). Occupational Ghettos: The Worldwide Segregation of Women and Men, Stanford, California: Stanford University Press.

Connell, R. (1987). Gender and Power: Society, the Person and Sexual Politics (First published ed.), Cambridge: Polity Press.

Davis, S. N., \& Greenstein, T. N. (2009). Gender ideology: Components, predictors, and consequences, Annual Review of Sociology 35(1): 87-105. doi: https://doi.org/10.1146/ annurev-soc-070308-115920.

Dodge, M., Valcore, L., \& Gomez, F. (2011). Women on SWAT teams: separate but equal? Policing: An International Journal of Police Strategies \& Management 34(4): 699-712. doi: https://doi.org/10.1108/13639511111180298.

Ellingsæter, A. L., \& Solheim, J. (2002). Den usynlige hånd? Kjønnsmakt og moderne arbeidsliv [The invisible hand? Gender power and modern work life], Oslo: Gyldendal Akademisk.

Ellingsæter,A. L. (2013). Scandinavian welfare states and gender (de)segregation, Economic and Industrial Democracy 34(3): 501-518. doi: https://doi.org/10.1177/0143831x13491616.

Finstad, L. (2000). Politiblikket [The police gaze], Oslo: Pax.

Finstad, L. (2014). Det konfliktfylte politiarbeidet [The conflict-filled police work]. In P. Larsson, H. O. Gundhus \& R. Granér (Eds.), Innføring i politivitenskap (pp. 229-254), Oslo: Cappelen Damm akademisk.

Freidson, E. (2001). Professionalism: The Third Logic, Cambridge: Polity Press.

Gherardi, S. (1994). The gender we think, the gender we do in our everyday organizational lives, Human Relations 47(6): 591-610.

Granér, R. (2004). Patrullerande polisers yrkeskultur [The professional culture of patrol officers], Lund: Socialhögskolan, Lund University.

Gundhus, H. (2009). For sikkerhets skyld - IKT, yrkeskulturer og kunnskapsarbeid i politiet. [A matter of safety - ICT, professionel cultures and knowledge work in the police], Oslo: Unipub. 
Gundhus, H. I. (2013). Experience or knowledge? Perspectives on new knowledge regimes and control of police professionalism, Policing 7(2): 178-194. doi: https://doi.org/10.1093/ police/pas039.

Holt, H., Geerdsen, L. P., Christensen, G., Klitgaard, C., \& Lind, M. L. (2006). Det kønsopdelte arbejdsmarked [The gender divided labor market], Socialforskningsinstituttet.

Holt, H., \& Lewis, S. (2011). 'You can stand on your head and still end up with lower pay': Gliding segregation and gendered work practices in danish 'Family-friendly' workplaces, Gender, Work \& Organization 18(1): 202-221. doi: https://doi.org/10.1111/j.14680432.2009.00501.x.

Inzunza, M. (2015). Empathy from a police work perspective, Journal of Scandinavian Studies in Criminology and Crime Prevention 16(1): 60-75. doi: https://doi.org/10.1080/140 43858.2014.987518.

Kanter, R. M. (1977). Some effects of proportions on group life: skewed sex ratios and responses to token women, American Journal of Sociology 82(5): 965-990. doi: https://doi. org/10.1086/226425.

Kanter, R. M. (1993). Men and Women of the Corporation (2. ed.), New York: Basic Books.

Karp, S., \& Stenmark, H. (2011). Learning to be a police officer. Tradition and change in the training and professional lives of police officers, Police Practice and Research 12(1): 4-15. doi: https://doi.org/10.1080/15614263.2010.497653.

Kjellmann, K. G., \& Møberg, R. J. (2018). Hvem er de politistuderende, og hvilke forestillinger gør de sig om politiarbejdet. [Who are the police recruits, and how do they perceive police work] Research paper, Aalborg: Aalborg universitet.

Lagestad, P. (2012). Physical skills and work performance in policing, International Journal of Police Science \& Management 14(1): 58-70. doi: https://doi.org/10.1350/ijps.2012.14.1.259.

Lander, I. (2013). Obstacles for changes within the (swedish) police force: Professional motivations, homosociality, and ordering practices, Journal of Scandinavian Studies in Criminology and Crime Prevention 14(1): 43-61. doi: https://doi.org/10.1080/14043858.2013.773691.

Larsson, P. (2010). Fra armsterke bondesønner til akademikerbarn: Om rekrutteringen til politiyrket [From strong peasant sons to academic children: Recruitment to the police profession], Nordisk Tidsskrift for Kriminalvidenskab 97(2): 150-159.

Löfstrand, C. H., \& Uhnoo, S. (2014). Diversity policing-policing diversity: Performing ethnicity in police and private-security work in Sweden, Social Inclusion 2(3): 75-87. doi: https://doi.org/10.17645/si.v2i3.40.

Loftus, B. (2010). Police occupational culture: Classic themes, altered times, Policing and Society 20(1): 1-20. doi: https://doi.org/10.1080/10439460903281547.

Mikkelsen, L. (2018). Konkret eller abstrakt politiarbejde? Politistuderendes vurderinger af motivationsfaktorer i politiopgaver [Specific or abstract police work? Police students' assessments of motivational factors in police tasks], Nordisk Politiforskning 5(1): 28-49. doi: https://doi.org/10.18261/issn.1894-8693-2018-01-04.

Nordberg, T. (2018). Intern kjønnssegregering i politiet - lederes oppfatninger om ansattes kjønnede kompetanse og tidsbruk [Gender segregation within the police - Leaders' perception of gendered competence and time use], Tidsskrift for Samfunnsforskning 59(4): 373-392. doi: https://doi.org/10.18261/issn.1504-291X-2018-04-03.

Olofsson, G., \& Petersson, O. (2011). Med sikte på profession: Akademiska yrkesutbildningar vid ett nytt universitet [Regarding the profession: Academic vocational education at a new university], Lund: Ariadne.

Petersson, O. (2015). Att bli polis. från utbildningens förväntningar till gatans norm [Becoming a police officer. from the expectations of education to the street norm], Stockholm: Norstedts Juridik.

POD. (2018). Politiets årsrapport 2017 [police annual report 2017], Oslo: Politidirektoratet. 
Podsakoff, P. M., MacKenzie, S. B., Lee, J., \& Podsakoff, N. P. (2003). Common method biases in behavioral research: A critical review of the literature and recommended remedies, Journal of Applied Psychology 88(5): 879-903. doi: https://doi.org/10.1037/00219010.88.5.879.

Prenzler, T., \& Sinclair, G. (2013). The status of women police officers: An international review. International Journal of Law, Crime and Justice 41(2): 115-131. doi: https://doi. org/10.1016/j.ijlcj.2012.12.001.

Reiner, R. (2010). The Politics of the Police (4. ed.), Oxford: Oxford University Press.

Reisel, T., \& Teigen, M. (2014). Kjønnsdeling og etniske skiller på arbeidsmarkedet [Gender division and ethnic differences in the labor market], Oslo: Gyldendal akademisk.

Rigspolitiet. (2018). HR-nøgletal [Key figures of HR], København: Rigspolitiet.

SCB. (2018). Anställda 16-64 år i riket efter yrke (4-siffrig SSYK 2012), arbetsställets sektortillhörighet och kön. år 2014-2016 [Employees 16-64 years of age in the state by occupation (4-digit SSYK 2012), workplace sector affiliation and gender. year 2014-2016] Statistics Sweden.

Slot, L. V. (2012). Etnisk mangfoldighed i politiet [Ethnic diversity in the police], København: Institut for Menneskerettigheder.

Solheim, J. (2002). Kjønn, kompetanse og hegemonisk makt. [Gender, competence, and hegemonic power]. In A. L. Ellingsæter, \& J. Solheim (Eds.), Den usynlige hånd. Kjønnsmakt og moderne arbeidsliv (pp. 110-140), Oslo: Gyldendal.

Teigen, M., \& Skjeie, H. (2017). The nordic gender equality model. In O. Knutsen (Ed.), The nordic models in political science. challenged but still viable? (pp. 125-148), Bergen: Fakbogforlaget.

Terpstra, J. B., \& Schaap, D (2013). Police culture, stress conditions and working styles, European Journal of Criminology 10(1): 59-73. doi: https://doi.org/10.1177/147737 0812456343.

Van Maanen, J. (1973). Working the Street; a Developmental View of Police Behavior, Massachusetts: Sloan School of Management, MIT.

Wharton, A. S. (2005). The Sociology of Gender: An Introduction to Theory and Research, Malden, Mass: Blackwell.

\section{Notes}

${ }^{1}$ In the event that a respondent only answered two out of the three questions, the combined score is divided by two. This solution minimizes deletion due to missing responses.

${ }^{2}$ Answered in the middle category of the question, 'neither agree nor disagree' to the statement in the question.

${ }^{3}$ Pearson $\mathrm{Chi}^{2}=24.27, \mathrm{df}=4, \mathrm{p}<0.001$.

${ }^{4}$ Wilcoxon Signed-ranks, $Z=0.960, p=0.3369$.

${ }^{5}$ Wilcoxon Signed-ranks, $\mathrm{Z}=0.911, \mathrm{p}=0.3623$.

${ }^{6}$ Pearson $\mathrm{Chi}^{2}=55.59, \mathrm{df}=4, \mathrm{p}<0.001$.

${ }^{7}$ Wilcoxon Signed-ranks, $Z=-0.955, p=0.3398$.

${ }^{8}$ Wilcoxon Signed-ranks, $\mathrm{Z}=-8.055, \mathrm{p}<0.001$.

${ }^{9}$ Wilcoxon Signed-ranks, $\mathrm{Z}=5.463, \mathrm{p}<0.001$.

${ }^{10}$ In phase two, there is a difference between male and female police recruits (Pearson Chi2 $=12.45$, $\mathrm{df}=4, \mathrm{p}<0.014)$ and a statistically significant decrease in the proportion of male police recruits agreeing to the statement (Wilcoxon signed-ranks, $\mathrm{Z}=5.752, \mathrm{p}<0.001$ ).

${ }^{11}$ If we, for example, compare a 20 -year-old police recruit with a police recruit who is 30 years old, the oldest police recruit is predicted to score 0.3 points lower on the scale of gendered competencies, which ranges from 0 to 4 . 